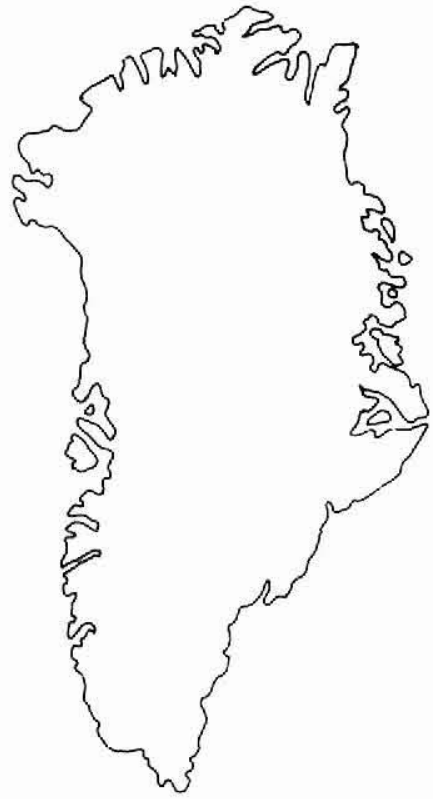

\title{
Degree-day factor, energy balance, and the increased melting of the Greenland ice sheet under a warmer climate
}

\author{
Roger J. Braithwaite
}

\begin{abstract}
Ablation on the Greenland ice sheet can be calculated cither from the degree-day factor or by an energy balance model. Both approaches involve problems, i.e. the degree-day factor varies with time and space while the energy balance model requires data which are often not available. The solution is to understand, and possibly predict, variations in degree-day factor. This can be attempted by (1) sensitivity experiments with the energy balance model, and (2) field studies of ablation under widely varying climate conditions.
\end{abstract}

R. J. B., Geological Survey of Greenland, Oster Voldgade 10, DK-1350 Copenhagen $K$, Denmark.

An increased 'greenhouse effect' will cause climatic warming, increased melting of glaciers including the Greenland ice sheet, and a rise in world sea level (Warrick \& Oerlemans, 1990). This has given a new focus to GGU's glaciological work, as well as stimulating other organisations to start research in Greenland, to make better assessments of the melting of the whole Greenland ice sheet. Recent progress is reviewed by Braithwaite et al. (this volume) while the present note discusses a technical problem involved in the assessment of melting on the Greenland ice sheet.

The background data for the present discussion are the ablation measurements made at the so-called 'daily stakes' at the margins of Nordbogletscher (Stake 53, 880 $\mathrm{m}$ a.s.1.) and Qamanârssûp sermia (Stake 751, $790 \mathrm{~m}$ a.s.l.) (Fig. 1) as described by Olesen \& Braithwaite (1989).

\section{Degree-day approach}

The degree-day approach assumes a relationship between melting and air temperatures above the melting point. The amount of ice or snow melted (in water equivalent) is proportional to the positive degree days sum, i.e. sum of positive temperatures, at the same place, and in the same period. The ratio of the two quantities is the degree-day factor which is assumed to be constant so that melting in any period can be calculated from the degree day sum in the same period. The degree-day model, involving only one parameter, is a simplification of a more general two-parameter model
(Braithwaite \& Olesen, 1989) but is used here for convenience of discussion.

The effect of climate change on ablation can be simulated by suitably adjusting the temperature data, and then re-calculating the amount of melt assuming that the degree-day factor does not change with climate.

The degree-day method was first used in the Alps by Finsterwalder \& Schunk (1887), has been tested by Braithwaite \& Olesen (1985 \& 1989) under Greenland

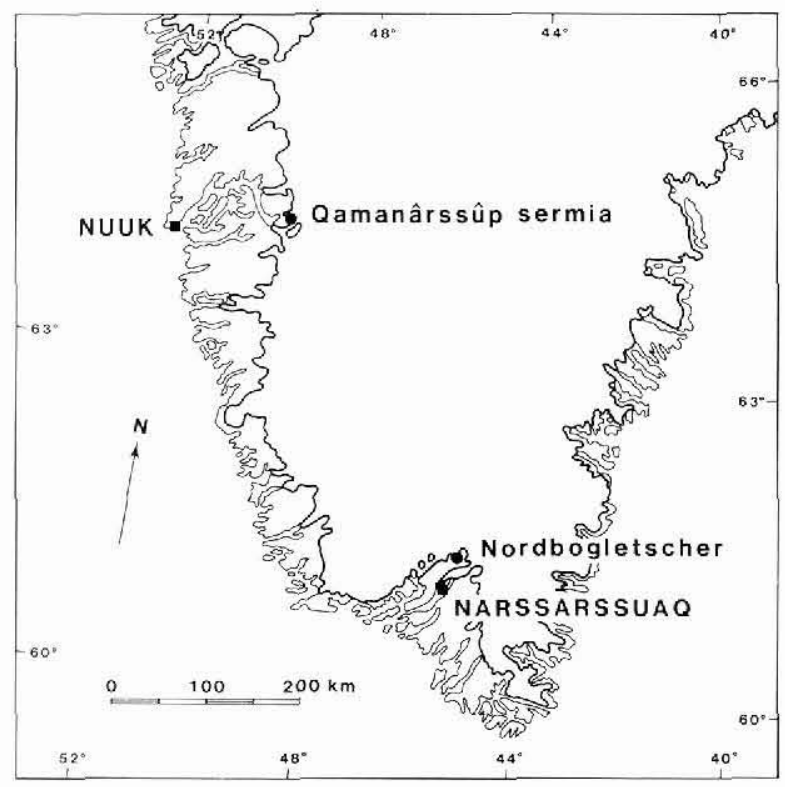

Fig. 1. Locations of two GGU glacier-climate stations. 


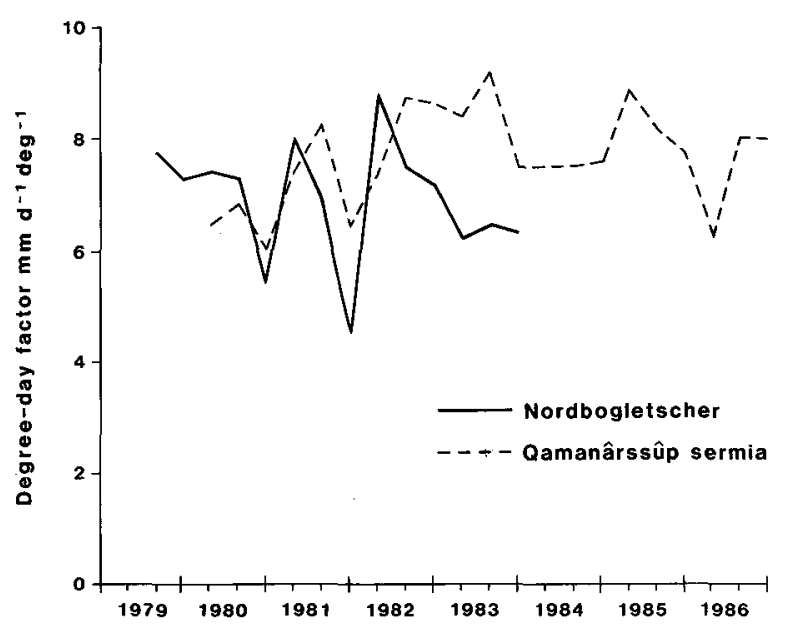

Fig. 2. Monthly degree-day factors at Nordbogletscher and Qamanârssûp sermia.

conditions, modified by Reeh (1991) to calculate melting over the whole Greenland ice sheet, and used in model simulations by Huybrechts et al. (1991) and Letréguilly et al. (1991).

There is a substantial difference between degree-day factors for ice and snow surfaces, e.g. values of 7.2 and $2.5 \mathrm{~mm} \mathrm{~d}^{-1} \mathrm{deg}^{-1}$ on Nordbogletscher, South Greenland (Braithwaite \& Olesen, 1988), but even degree-day factors for ice surfaces vary with time and space. As an example, variations in monthly values at two GGU field stations are shown in Fig. 2.

The mean degree-day factors for different months at each site (Table 1) are not significantly different (5 percent level) from each other according to the paired t-test and one-way analysis of variance (Kreyszig, 1970, p. $178-180$ \& p. $263-265$ respectively). The means of the full samples for each site (14 and 21 months) are, however, significantly different ( 5 per cent level) ac- cording to the 2-sample t-test (Kreyszig, 1970, p. 209210). There is also little correlation between degree-day factors at the two sites so their variations can be regarded as more or less random.

\section{Energy balance}

A more fundamental approach involves assessment of the energy fluxes to and from the glacier surface, and calculation of the melting from the available energy, i.e. energy balance, at the glacier surface. The approach involves careful and difficult measurements of both short- and long-wave radiation transfer, and latent and sensible heat fluxes in the turbulent boundary layer immediately over the glacier. Such measurements have been made earlier in both the ablation and accumulation areas of the Greenland ice sheet by Ambach (1963 \& 1977). New measurements have also been made in West Greenland in 1990-1991 by Dutch and Swiss groups with improved instruments for radiation and turbulence, including sonic anemometers for the first direct measurements of turbulent fluxes in Greenland.

As a supplement to the measurement of energy balance, Ambach (1986) has proposed a relatively simple procedure to calculate energy balance from basic climate data which Braithwaite \& Olesen (1990a) modified with a long-wave radiation formula from Ohmura (1981). The operation of the model is shown in Fig. 3 and allows estimation of the energy balance from a few simple climate variables: air temperature, humidity, wind speed, cloud amount, and short-wave radiation, as well as an indication of whether the glacier surface is snow or ice.

The calculated average energy balances for the summer months June-August at Nordbogletscher and Qamanârssûp sermia are illustrated in Fig. 4. In both cases,

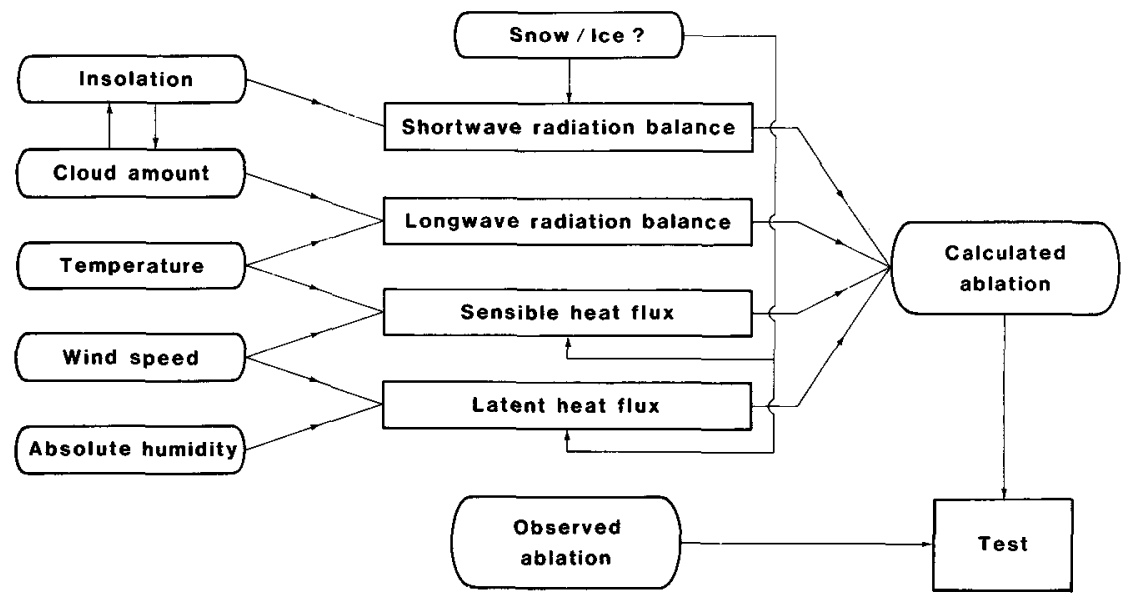

Fig. 3. Calculation of ablation by a simple energy-balance model (Braithwaite \& Olesen, 1990c). 
ablation mainly refers to ice (with occasional falls of new snow) and the error (including terms neglected by the model) is reasonably small. Ablation at Qamanârssûp sermia is generally higher than at Nordbogletscher because of higher sensible heat flux (higher temperatures and wind speed) and higher short-wave radiation (lower cloudiness).

\section{The problem}

The assessment of ablation over the whole Greenland ice sheet by Reeh (1991) raises an awkward question: how does the degree-day factor vary with location? A similar question on time variations is posed by longterm simulations of mass-balance, e.g. by Letréguilly et al. (1991). These points are not made to criticise the quoted studies (which certainly make the best use of available information) but simply to illustrate the need to understand, and possibly predict, time and space variations in degree-day factor.

At first glance, the energy balance model seems an attractive alternative for assessing ablation over the whole Greenland ice sheet. However, even the simple model in Fig. 3 requires data which are not generally available with the exception of temperature which can be readily extrapolated. Naturally, the energy balance model can be further simplified but only by losing its 'physical' character which is its main appeal. For example, there is an important interaction between temperature and wind speed (Braithwaite \& Olesen, 1990b) which is overlooked if variations in wind speed are neglected as being unknown. Interaction between the short- and long-wave radiation components by way of their separate dependency on cloud conditions is also important.

To summarise, assessment of melting on the whole Greenland ice sheet using the degree-day approach involves the problem of an uncertain parameter (the degree-day factor) while the energy balance approach involves uncertainties in most of the input data.

\section{Synthesis}

Within limits it should be possible to explain variations in the degree-day factor in terms of energy balance (Ambach, 1988; Braithwaite \& Olesen, 1990b) so that likely variations can be estimated, and possibly associated with some scheme of climatic classification.

In both the present cases (Fig. 4), radiation is on average the largest source of ablation energy, but the turbulent fluxes are more variable. Ablation variations are therefore controlled mainly by variations in the turbulent fluxes and, as these depend to a high degree on temperature (Braithwaite \& Olesen, 1990b), this is the 'physical' basis of ablation-temperature models.

More than half the average temperature response of ablation at both sites is accounted for by sensible heat flux, and only a quarter by net radiation (Braithwaite \& Olesen, 1990b). There are, however, differences between the sites whereby sensible-heat flux, latent heat flux and short-wave radiation all have higher temperature responses at Qamanârssûp sermia compared with
Fig. 4. Simulated June-August energy balance at Nordbogletscher and Qamanârssûp sermia (Braithwaite \& Olesen, 1990a).
Ablation sources

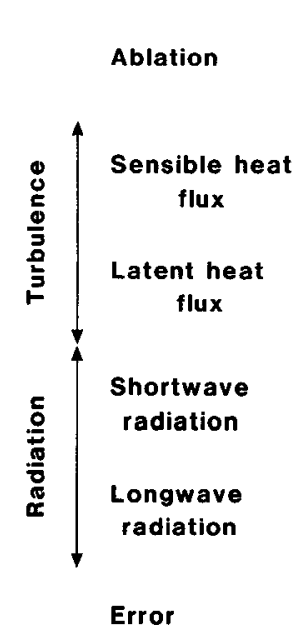

Error
Nordbogletscher Qamanârssûp sermia
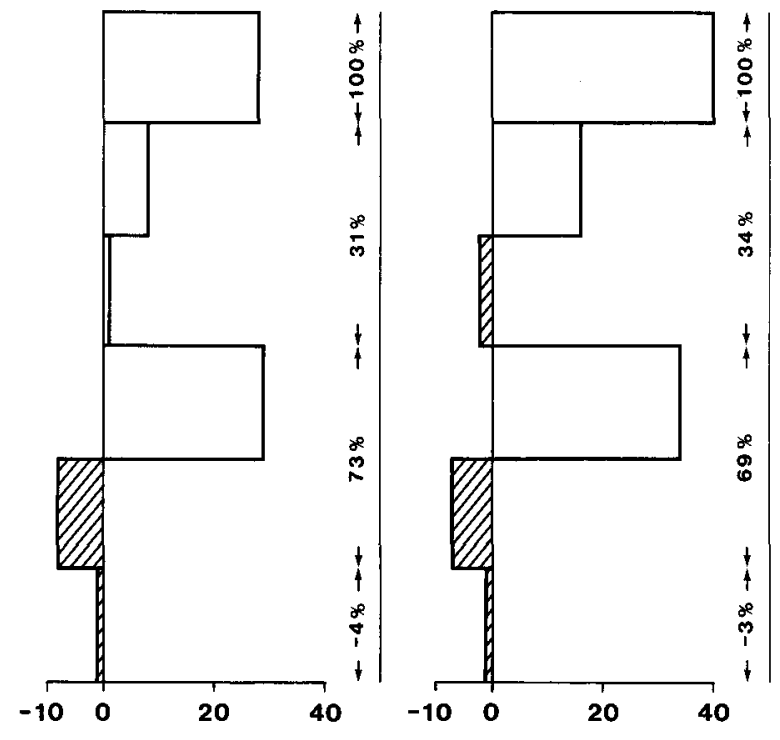

Ablation energy $\mathrm{mm}$ water/day 


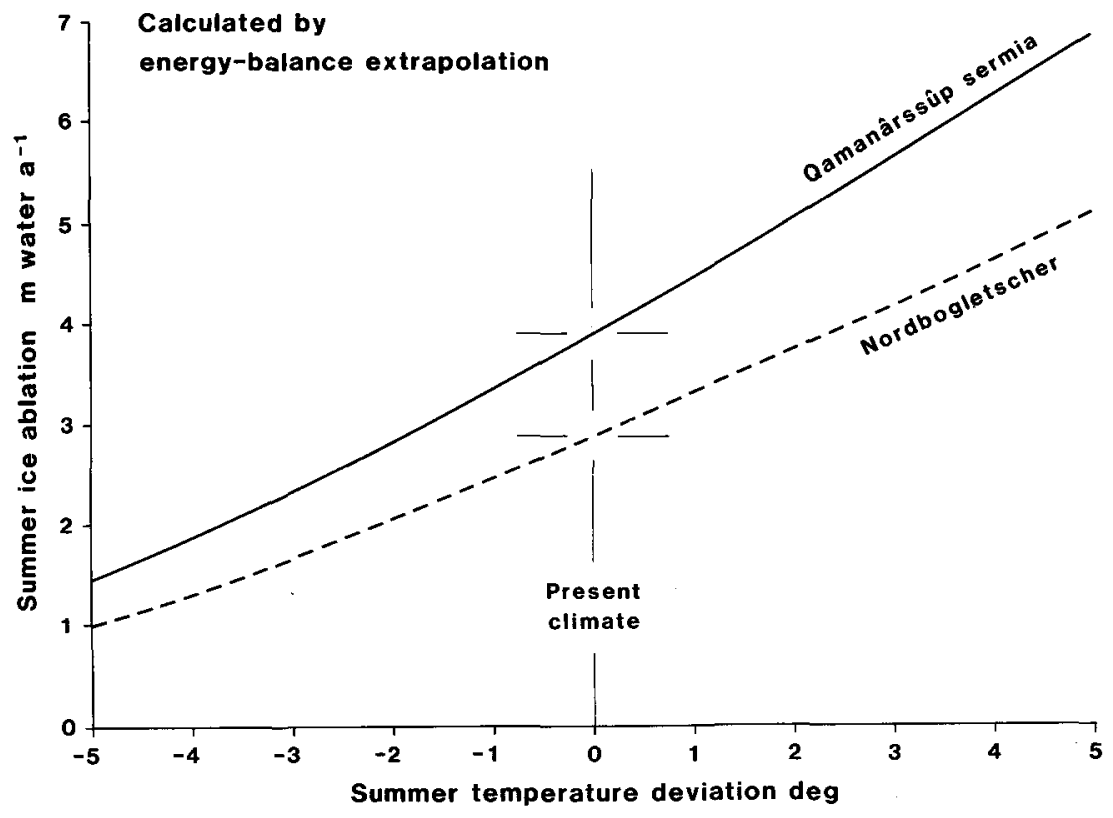

Fig. 5. Simulated June-August ice ablation at Nordbogletscher and Qamanârssûp sermia as a function of summer temperature (Braithwaite \& Olesen, 1990c).

Nordbogletscher, i.e. the climate is slightly more continental.

The difference in temperature response of the energy balance at the two sites is also demonstrated by recalculation of the energy balance as a function of temperature (Braithwaite \& Olesen, 1990c). Summer ablation at Qamanârssûp sermia, i.e. for June-August, increases with summer mean temperature at a greater rate than summer ablation at Nordbogletscher (Fig. 5) in agreement with the higher degree-day factors in Table 1.

\section{Outlook}

The above discussion suggests strongly that space variations in degree-day factor can be explained in terms of the energy balance. A future strategy of studying time and space variations of degree-day factor can therefore be based on two elements: (1) sensitivity experiments with the energy balance model, and (2) field studies of ablation under widely varying climate conditions.

The energy balance model has already been used for some experiments by Braithwaite \& Olesen (1990b), e.g. effects of wind speed variations and surface conditions, and this work can continue as an office project. One priority will be to try to explain the time variations of degree-day factor at each site (Table 1).

Field studies of ablation should be made under both extremes of dry-continental and wet-maritime conditions. For example, the Alfred Wegener Institute for Polar Research (AWI), Bremerhaven, Germany, made ablation-climate studies in North-East Greenland 19891990 and will return again in 1992 (Oerter \& Reeh, 1991).

Table 1. Monthly degree-day factor for two glaciers in West Greenland. Units are $m m$ water $d^{-1}$ deg $^{-1}$

\begin{tabular}{lrrrr}
\hline Year & June & July & August & Mean \\
& & & \\
\multicolumn{5}{l}{ Nordbogletscher, Stake } \\
\multicolumn{5}{c}{ 53, 880 m a.s.l. } \\
1979 & 7.73 & 7.25 & $(7.49)$ \\
1980 & 7.39 & 7.27 & 5.44 & 6.70 \\
1981 & 8.03 & 6.88 & 4.53 & 6.48 \\
1982 & 8.85 & 7.49 & 7.17 & 7.84 \\
1983 & 6.24 & 6.47 & 6.35 & 6.35 \\
Mean & 7.63 & 7.17 & 6.15 & 6.97 \\
S.D. & \pm 1.10 & \pm 0.50 & \pm 1.16 & \pm 0.66
\end{tabular}

Qamanârssûp sermia, Stake 751, 790 m a.s.l.

\begin{tabular}{lrrrr}
1980 & 6.47 & 6.82 & 6.05 & 6.45 \\
1981 & 7.40 & 8.26 & 6.45 & 7.37 \\
1982 & 7.38 & 8.73 & 8.66 & 8.26 \\
1983 & 8.44 & 9.24 & 7.51 & 8.40 \\
1984 & 7.53 & 7.55 & 7.63 & 7.57 \\
1985 & 8.93 & 8.23 & 7.80 & 8.32 \\
1986 & 6.33 & 8.09 & 8.07 & 7.50 \\
Mean & 7.50 & 8.13 & 7.45 & 7.69 \\
S.D. & \pm 0.95 & \pm 0.78 & \pm 0.91 & \pm 0.70 \\
\hline
\end{tabular}


External support is also being sought by GGU for reconnaissance studies of ablation in North Greenland for 1993-1994 and possibly longer. However, ablation studies should also be made at some time in the very wet area of South-East Greenland where there are presently no data. The basic techniques will follow those used at Nordbogletscher and Qamanârssûp sermia (Olesen \& Braithwaite, 1989) with daily readings of ablation and parallel measurements of simple climate elements: air temperature, wind speed, humidity, cloud amount and short-wave radiation. However, both albedo variations and heat conduction into the ice, previously neglected, must be measured in a future GGU programme. It is also hoped to operate high-quality radiation instruments (in cooperation with a foreign partner) to study effects of solar and atmospheric radiation on the degree-day factor.

\section{References}

Ambach, W. 1963: Untersuchungen zum Energieumsatz in der Ablationszone des grönländisches Inlandeises. Meddr Grønland 174(4), 311 pp.

Ambach, W. 1977: Untersuchungen zum Energieumsatz in der Akkumulationszone des grönländisches Inlandeises. Meddr Grønland 187(7), 45 pp.

Ambach, W. 1986: Nomographs for the determination of meltwater from snow and ice surfaces. Ber. nat.-med. Verein Innsbruck 73, 7-15.

Ambach, W. 1988: Heat balance characteristics and ice ablation, western EGIG-profile, Greenland. In Thomsen, T., Søgaard, H. \& Braithwaite, R. J. (ed.) Applied hydrology in the development of northern basins, 59-70. Copenhagen: Danish Society for Arctic Technology.

Braithwaite, R. J. \& Olesen, O. B. 1985: Ice ablation in West Greenland in relation to air temperature and global radiation. Z. Gletscherk. Glazialgeol. 20, 155-168.

Braithwaite, R. J. \& Olesen, O. B. 1988: Winter accumulation reduces summer ablation on Nordbogletscher, South Greenland. Z. Gletscherk. Glazialgeol. 24(1), 21-30.
Braithwaite, R. J. \& Olesen, O. B. 1989: Calculation of glacier ablation from air temperature, West Greenland. In Oerlemans, J. (ed.) Glacier fluctuations and climatic change, 219233. Dordrecht: Kluwer Academic Publishers.

Braithwaite, R. J. \& Olesen, O. B. 1990a: A simple energybalance model to calculate ice ablation at the margin of the Greenland ice sheet. J. Glaciol. 36(123), 222-228.

Braithwaite, R. J. \& Olesen, O. B. 1990b: Response of the energy balance on the margin of the Greenland ice sheet to temperature changes. J. Glaciol. 36(123), 217-221.

Braithwaite, R. J. \& Olesen, O. B. 1990c: Increased ablation at the margin of the Greenland ice sheet under a greenhouse-effect climate. Ann. Glaciol. 14, 20-22.

Braithwaite, R. J., Reeh, N. \& Weidick, A. 1992: Greenland glaciers and the 'greenhouse effect', status 1991. Rapp. Grønlands geol. Unders. 155 (this volume).

Finsterwalder, S. \& Schunk, H. 1887: Der Suldenferner. $Z$. dt. oest. Alpenver. 18, 72-89.

Huybrechts, P., Letréguilly, A. \& Reeh, N. 1991: The Greenland ice sheet and greenhouse warming. Palaeogeogr. Palaeoclim. Palaeoecol. (Global planet. Change Sect.) 89, 399412.

Kreyszig, E. 1970: Introductory mathematical statistics, $470 \mathrm{pp}$. New York: John Wiley.

Letréguilly, A., Huybrechts, P. \& Reeh, N. 1991: Steady-state characteristics of the Greenland ice sheet under different climates. J. Glaciol. 37(125), 149-157.

Oerter, H. \& Reeh, N. 1991: Ablationsstudie am Storstrømmen, Nordostgrönland, 1989-1990. Programm, 16th. Internationale Polartagung in Göttingen 10-13 April 1991.

Ohmura, A. 1981: Climate and energy balance on arctic tundra, Axel Heiberg Island, Canadian Arctic Archipelago. Zürcher Geogr. Schrift. 3, 448 pp.

Olesen, O. B. \& Braithwaite, R. J. 1989: Field stations for glacier-climate research, West Greenland. In Oerlemans. J. (ed.) Glacier fluctuations and climatic change, 207-218. Dordrecht: Kluwer Academic Publishers.

Reeh, N. 1991. Parameterization of melt rate and surface temperature on the Greenland ice sheet. Polarforschung 59(3), 113-128.

Warrick, R. \& Oerlemans, J. 1990: Sea level rise. In Houghton, J. T., Jenkins, G. J. \& Ephraums, J. J. (ed.) Climate change - the IPCC scientific assessment, 257-281. Cambridge: Cambridge University Press. 